Article

\title{
Ratio of Mercury Concentration to PCB Concentration Varies with Sex of White Sucker (Catostomus commersonii)
}

\author{
Charles P. Madenjian ${ }^{1, *}$, Andrew L. Stevens ${ }^{2}$, Martin A. Stapanian ${ }^{3}$, David P. Krabbenhoft ${ }^{4}$, \\ John F. DeWild ${ }^{4}$, Jacob M. Ogorek ${ }^{4}$, William H. Edwards ${ }^{3}$, Lynn M. Ogilvie ${ }^{1}$ \\ and Peter B. McIntyre 5 \\ 1 U.S. Geological Survey, Great Lakes Science Center, 1451 Green Road, Ann Arbor, MI 48105, USA; \\ logilvie@usgs.gov \\ 2 U.S. Fish and Wildlife Service, Ashland Fish and Wildlife Conservation Office, 2800 Lakeshore Drive East \\ Ashland, WI 54806, USA; andrew_stevens@fws.gov \\ 3 U.S. Geological Survey, Great Lakes Science Center, Lake Erie Biological Station, 6100 Columbus Avenue, \\ Sandusky, OH 44870, USA; mstapanian@usgs.gov (M.A.S.); wedwards@usgs.gov (W.H.E.) \\ 4 U.S. Geological Survey, Upper Midwest Water Science Center, 8505 Research Way, Middleton, WI 53562, \\ USA; dpkrabbe@usgs.gov (D.P.K.); jfdewild@usgs.gov (J.F.D.); jmogorek@usgs.gov (J.M.O.) \\ 5 Center for Limnology, University of Wisconsin, 680 North Park Street, Madison, WI 53706, USA; \\ pmcintyre@wisc.edu \\ * Correspondence: cmadenjian@usgs.gov; Tel.: +1-734-214-7259; Fax: +1-734-994-8780
}

Received: 4 July 2018; Accepted: 21 August 2018; Published: 24 August 2018

\begin{abstract}
The whole-fish total mercury $(\mathrm{Hg})$ concentrations were determined in 25 mature female and 26 mature male white suckers (Catostomus commersonii) caught during their spawning run in the Kewaunee River, a tributary to Lake Michigan. The age of each fish was estimated using thin-sectioned otoliths, and total length (TL) and weight were determined for each fish. When adjusted for the effect of age, males were found to be $7 \%$ higher in $\mathrm{Hg}$ concentration than females. Nearly all (about $98 \%$ ) of the $\mathrm{Hg}$ found in the white suckers was determined to be methylmercury. In an earlier study on the same 51 white suckers from the Kewaunee River spawning run, males were found to be $18 \%$ higher than females in polychlorinated biphenyl (PCB) concentration. We determined that the ratio of $\mathrm{Hg}$ concentration to $\mathrm{PCB}$ concentration in females was significantly higher than that in males. Thus, sex significantly interacted with contaminant type (Hg or PCBs) in determining contaminant concentrations. The most plausible explanation for this interaction was that males eliminated $\mathrm{Hg}$ at a faster rate than females, most likely due to the boosting of the Hg-elimination rate by certain androgens such as testosterone and 11-ketotestosterone. $\mathrm{Hg}$ concentrations in the white suckers were well below federal guidelines for fish consumption.
\end{abstract}

Keywords: catostomids; fish consumption advisories; Hg; PCBs; sex differences; white sucker

\section{Introduction}

Although mercury is a naturally occurring element on Earth, human activity has led to widespread mercury contamination of terrestrial and aquatic ecosystems [1,2]. Mercury tends to biomagnify in food webs, resulting in top predators, including humans, attaining elevated mercury concentrations $[2,3]$. The primary route of exposure of mercury to humans is via the consumption of fish [1-4]. Among the most serious threats to human health from mercury contamination is the impairment of normal brain development in the fetus [5-11]. Other toxic effects of mercury on humans include damage to the nervous system of adults, damage to the renal system, damage to the immune 
system, and damage to the cardiovascular system. Further, recent research has revealed that the risk of reproductive-age women acquiring autoimmune disease increases with increasing mercury exposure [12]. Determinations of mercury concentrations in fish fulfill essential roles both in developing fish consumption advisories and in assessing risk to humans and wildlife consuming contaminated fish [7,13-17]. Within an aquatic ecosystem, mercury can be found in its inorganic form or in the form of methylmercury [1,2]. Typically, the predominant form of mercury in fish is methylmercury [18]. However, in some cases, inorganic mercury can represent a substantial component of the mercury found in fish [19].

Researchers have concluded that the dominant source of mercury to Lake Michigan is atmospheric deposition [20-23]. Mercury concentrations in the surface waters of Lake Michigan are comparable to those observed in the open oceans $(<0.5 \mathrm{ng} / \mathrm{L})$. Moreover, mercury concentrations in the sediments of Lake Michigan have been classified as representative of a lake without a substantial amount of enrichment emanating from human activities [21]. The lakewide average mercury concentration in the sediments of Lake Michigan was only 0.08 $\mu \mathrm{g} / \mathrm{g}$ during 1994-1996.

Albeit based on only four species of teleost fishes, a pattern has emerged with regard to discord between the relative difference in total mercury $(\mathrm{Hg})$ concentrations between the sexes and the relative difference in polychlorinated biphenyl (PCB) concentrations between the sexes [24]. Specifically, for a given population of mature fish, the ratio of $\mathrm{Hg}$ concentration in males to $\mathrm{Hg}$ concentration in females is less than the ratio of PCB concentration in males to PCB concentration in females. After considering several hypotheses for the difference between the two ratios, Madenjian et al. [24] concluded that this difference is most likely driven by males excreting $\mathrm{Hg}$ from their bodies at a substantially faster rate than females. In contrast, long-term elimination of PCBs has been characterized as negligible for both sexes. A recent study showing that the Hg-elimination rate for the male northern pike (Esox lucius) was more than double that for the female northern pike provided support for the abovementioned conclusion [25]. The faster rate of $\mathrm{Hg}$ elimination in males has been attributed to the boosting of the Hg-elimination rate by certain androgens, such as testosterone and 11-ketotestosterone.

White sucker (Catostomus commersonii), a benthic fish, is prolific and widely distributed across North America [26,27]. This species is ecomorphologically specialized for feeding on benthic algae and benthic invertebrates. Large aggregations of white suckers migrate each spring from larger bodies of water to small tributaries to spawn, thereby providing important nutrient inputs to stream ecosystems [28]. People eat white suckers throughout the range for this species [29,30]. White suckers are frequently sought after by anglers fishing tributaries to the Laurentian Great Lakes [30]. In addition, commercial fisheries continue to harvest white suckers from the Laurentian Great Lakes. The white sucker has been classified as a sentinel species for habitat degradation and contaminated sediments in aquatic ecosystems [31,32].

Establishing that the ratio of $\mathrm{Hg}$ concentration to $\mathrm{PCB}$ concentration is higher in females than in males from a white sucker population would be an important step in documenting the degree of prevalence among fish populations of the abovementioned pattern between $\mathrm{Hg}$ concentration, $\mathrm{PCB}$ concentration, and sex. This pattern has yet to be demonstrated in an omnivorous fish like the white sucker. Further, this kind of research effort would fulfill one of the recommended future research activities for the study of sex differences in contaminant concentrations of fish [24]. The ratio of PCB concentration in males to PCB concentration in females has equaled 1.22, 1.29, 1.34, and 1.43 for lake trout (Salvelinus namaycush), burbot (Lota lota), lake whitefish (Coregonus clupeaformis), and summer flounder (Paralichthys dentatus), respectively, while the respective ratios of $\mathrm{Hg}$ concentration in males to $\mathrm{Hg}$ concentration in females were equal to $1.08,0.82,0.91$, and 0.98 [24]. The difference between the two ratios for a specific fish population may be related to the degree of difference in the Hg-elimination rates between the sexes [24]. The greater the difference in the Hg-elimination rates between the sexes, the greater the difference between the two ratios.

The overall goals of our study were to depict mercury accumulation in a white sucker population from Lake Michigan and then characterize the interaction between mercury, PCBs, and sex in the 
white sucker population. Specific objectives included the following: (1) quantify the difference in whole-fish $\mathrm{Hg}$ concentrations between the sexes of white suckers from Lake Michigan, (2) discuss the potential causes for the observed sex difference in the $\mathrm{Hg}$ concentrations and then identify the most likely cause or causes, (3) estimate the proportion of $\mathrm{Hg}$ represented by methylmercury in the white suckers, (4) determine whether sex significantly interacted with $\mathrm{Hg}$ and PCB concentrations in mediating the contaminant concentrations found in the white suckers, (5) identify the most likely cause for the abovementioned interaction or lack thereof, and (6) discuss the implications of our findings with regard to the fish consumption advisories for white suckers from the Kewaunee River population based on the observed $\mathrm{Hg}$ concentrations. Ultimately, we wanted to determine whether the white sucker results continued to support the emerging pattern of ratio of PCB concentration in males to $\mathrm{PCB}$ concentration in females exceeding the ratio of $\mathrm{Hg}$ concentration in males to $\mathrm{Hg}$ concentration in females. To examine the mercury-PCB-sex interaction, we relied on whole-fish PCB data from an earlier study [33], which was based on the same white suckers used in our study.

\section{Materials and Methods}

\subsection{Field Methods}

Field methods for catching the white suckers were described in detail by Madenjian et al. [33], and a brief summary of those methods follows below. Dip nets were used to catch 25 female and 26 male adult white suckers just below the dam at the C.D. "Buzz" Besadny Anadromous Fish Facility located on the Kewaunee River (Wisconsin, USA), a tributary to Lake Michigan. The sex of each fish was easily determined in the field, as males exhibited nuptial tubercles on their anal and caudal fins, and gametes were observed while handling the fish. We followed the American Fisheries Society's guidelines for the care and use of fishes when handling the white suckers [34], and all fish were euthanized with tricaine methanesulfonate (MS-222) after capture. For each fish, otoliths were extracted for estimating age, total length (TL) was measured to the nearest $\mathrm{mm}$, and weight was determined to the nearest $\mathrm{g}$. All fish were individually bagged, frozen at $-20^{\circ} \mathrm{C}$, and later transported to the United States (U.S.) Geological Survey (USGS) Great Lakes Science Center (GLSC) in Ann Arbor, Michigan, for further processing.

\section{2. $P C B, H g$, Methylmercury, and Age Determinations}

Each of the 51 white suckers was partially thawed and then homogenized using appropriately sized blenders at the GLSC, as described by Madenjian et al. [33]. For each white sucker, approximately $100 \mathrm{~g}$ of the whole-fish homogenate was transferred to each of two contaminant-free glass jars. Each jar was then sealed with a lid and stored at $-20{ }^{\circ} \mathrm{C}$. One glass jar filled with homogenate was added to the set of samples for PCB determinations, and the other glass jar filled with homogenate was added to the set of samples for mercury determinations. After all of the 51 white suckers were homogenized, one set of frozen homogenate samples was transported to the University of Michigan School of Public Health for PCB determinations. The other set of frozen homogenate samples was shipped to the USGS Mercury Research Laboratory (MRL) (http:/ / wi.water.usgs.gov/mercurylaboratory) in Middleton, Wisconsin, for $\mathrm{Hg}$ and methylmercury $(\mathrm{MeHg})$ determinations.

The procedures used to determine PCB concentrations in the whole-fish white sucker homogenates have been described by Madenjian et al. [33]. A dichloromethane/hexane mixture was used to extract the organic fraction from the whole-fish homogenate. Then, an acid cleanup was performed using sulfuric acid to extract the lipid fraction. Gas chromatography/mass spectrometry (GC/MS) was used to separate and quantify the PCBs.

The details of the standard operating procedures for all analytical procedures practiced by the MRL are provided at [35]. The total mercury $(\mathrm{Hg})$ determinations were conducted using a modification of United States Environmental Protection Agency (USEPA) method 7473, a high-temperature direct combustion analysis [36], on a Nippon MA-2 instrument. Briefly, homogenized, freeze-dried tissue 
samples were combusted at high temperature $\left(850^{\circ} \mathrm{C}\right)$ in the presence of interference-reducing reagents, releasing mercury from the matrix as reduced gaseous mercury. In the resulting gas, the matrix interference was further eliminated by catalytic treatment, adjusted to the appropriate $\mathrm{pH}$ in a phosphate buffer, and then passed through a gold amalgam trap to quantitatively capture the evolved gaseous mercury. Lastly, the gold trap was heated, releasing the bound mercury into the sample stream, and detected by cold vapor atomic absorption. Quality assurance and control protocols used throughout sample analysis included reagent blanks, sample replicates, and standard reference materials (SRMs). The sample runs were performed in blocks of 10 samples, with 1 sample being run in triplicate and the inclusion of 2 blanks and a SRM determination. Prior to the start of the sample analyses, 3-5 SRM determinations were made to evaluate the precision and accuracy of the instrument. For our white sucker samples, the relative standard deviation (RSD) from the triplicate analyses ranged from 0.6 to 3.9\% (mean of 1.7\%). International Atomic Energy Agency Reference Material 407 (IAEA 407), which is fish homogenate from fish caught in the North Sea in 1999, was used as the SRM. In total, 25 SRM determinations were made, and the average SRM recovery was $96 \%$. The limit of detection based on daily detection limit calculations, in accordance with USEPA protocol [37], was $1 \mathrm{ng} / \mathrm{g}$ (dry weight basis). All white sucker $\mathrm{Hg}$ concentrations were reported on a wet weight basis.

Methylmercury determination was conducted using the dilute nitric acid-extraction method developed by Hammerschmidt and Fitzgerald [38]. Briefly, the tissue sample was weighed into Teflon vials and digested in $5 \mathrm{M}$ nitric acid at $60^{\circ} \mathrm{C}$ for $8 \mathrm{~h}$. The sample extract was added to reagent water in $42 \mathrm{~mL}$ glass vials, titrated with an equivalent volume of $5 \mathrm{M}$ potassium hydroxide, and buffered with sodium acetate/acetic acid to a pH of 4.5-5.0. Sodium tetraethylborate (NaTEB) was added to the sample resulting in ethylation of the oxidized mercury species (both $\mathrm{Hg}^{2+}$ and $\mathrm{MeHg}^{+}$). The volatile ethylated species, as well as elemental mercury, were purged from the sample with argon gas, retained on Tenex traps, thermally desorbed back into the sample stream, and separated by mass with a gas chromatography column. The elemental and ethylated mercury species were released from the column en masse into the gas stream, thermally reduced to elemental mercury, and detected by cold vapor atomic fluorescent spectrometry (CVAFS). Quality assurance and control protocols included the following: method and analytical blanks, sample replication, and analysis of SRMs. We randomly selected 30 white suckers out of the 51 white suckers for methylmercury determinations. Triplicate analysis was run every 7 samples, and RSD ranged from 1.4 to $5.4 \%$ (mean of 3.2\%). IAEA 407 was used as the SRM, and 6 SRM determinations were made. Mean SRM recovery was $103 \%$. The limit of detection based on daily detection limit calculations, in accordance with USEPA protocol [37], was $2 \mathrm{ng} / \mathrm{g}$ (dry weight basis). All the white sucker methylmercury concentrations were reported on a wet weight basis.

The most reliable method for estimating the age of white suckers is to use thin-sectioned otoliths [39]. Thus, we prepared thin sections for each of the otoliths and followed the procedures described by Edwards et al. [40] to assign an age to each of the white suckers.

\subsection{Data Analyses}

To quantify the difference in the whole-fish $\mathrm{Hg}$ concentrations between the sexes of the white suckers, we considered four analysis of covariance (ANCOVA) models in which Hg concentration was the dependent variable, sex was the main effect, and TL, weight, Fulton's condition $K$ (equal to weight $\cdot 10^{5} \cdot \mathrm{TL}^{-3}$ ), or age was the covariate. A key assumption of the ANCOVA model is that the slopes of the regression lines are identical for all levels of the main effect. Therefore, we used an $F$ test for equality of slopes of regression lines to determine whether the slopes of the two regression lines were significantly different from one another. Of the four ANCOVA model applications considered, the only model application that both met the equality of slopes assumption and resulted in the regression line slopes significantly different from zero was the application with age as the covariate. Thus, we used the ANCOVA model application with age as the covariate to estimate the Hg concentration of both 
females and males at the value of age equal to the grand mean of ages of all 51 white suckers sampled. To estimate the relative difference in the $\mathrm{Hg}$ concentrations between the sexes, the estimate of the $\mathrm{Hg}$ concentration of males at the grand mean for age was divided by the estimate of the $\mathrm{Hg}$ concentration of females at the grand mean for age. For all of our statistical testing, $\alpha$ was set equal to 0.05 .

To determine the proportion of $\mathrm{Hg}$ in the white suckers represented by methylmercury $(\mathrm{MeHg})$, the fraction of $\mathrm{Hg}$ as $\mathrm{MeHg}$ was calculated by the ratio of $\mathrm{MeHg}$ concentration to $\mathrm{Hg}$ concentration for each of the 51 white suckers. The mean of these ratios was then calculated using data for all 51 white suckers. Mean ratios for each sex were also calculated.

To determine whether contaminant type (Hg or PCBs) significantly interacted with sex, we first calculated the ratio of the $\mathrm{Hg}$ concentration to the PCB concentration for each of the 51 white suckers. We then considered four ANCOVA models in which the ratio of $\mathrm{Hg}$ concentration to PCB concentration was the dependent variable, sex was the main effect, and TL, weight, $K$, or age was the covariate. The ANCOVA application that explained the greatest amount of variation in the dependent variable was then selected as the best model, and the significance of the sex effect in the best model application was tested. A significant difference generated from this test of the sex effect would indicate that sex significantly interacted with contaminant type, because the ratio of the $\mathrm{Hg}$ concentration to the PCB concentration would be found to significantly vary between the sexes. An $F$ test for equality of slopes was applied to determine whether the equality of slopes assumption was met.

\section{Results}

Of the 51 white suckers sampled in our study, the females were slightly older and considerably larger than the males (Table 1). The ages of the females ranged from 9 to 18 years, while the ages of the males ranged from 4 to 24 years. The females averaged 13.3 years in age, while the males averaged 12.9 years in age. The mean TL of the females was $490 \mathrm{~mm}$, whereas the mean TL of the males was $442 \mathrm{~mm}$. The mean weight of the females was $1298 \mathrm{~g}$, whereas the mean weight of the males was $868 \mathrm{~g}$ (Table 1). The females exhibited a slightly higher condition than the males.

Table 1. Mean (standard error of the mean enclosed with parentheses) \{range enclosed within brackets\} values for total length, weight, Fulton's condition $K$, age, polychlorinated biphenyl (PCB) concentration, total mercury $(\mathrm{Hg})$ concentration, methylmercury $(\mathrm{MeHg})$ concentration, and the proportion of $\mathrm{Hg}$ represented by $\mathrm{MeHg}$, by sex, of the white suckers caught in the Kewaunee River (Wisconsin, USA), a tributary to Lake Michigan, during April 2016.

\begin{tabular}{ccc}
\hline Attribute & Females & Males \\
\hline Total length $(\mathrm{mm})$ & $490(5)\{450-540\}$ & $442(6)\{375-510\}$ \\
Weight $(\mathrm{g})$ & $1298(43)\{885-1726\}$ & $868(33)\{490-1215\}$ \\
$\mathrm{K}$ & $1.095(0.016)\{0.970-1.271\}$ & $0.995(0.014)\{0.833-1.140\}$ \\
Age (years) & $13.3(0.5)\{9-18\}$ & $12.9(0.9)\{4-24\}$ \\
PCB concentration (ng/g) & $192(12)\{104-310\}$ & $213(9)\{93-311\}$ \\
Hg concentration $(\mathrm{ng} / \mathrm{g})$ & $100(3)\{66-134\}$ & $105(6)\{44-185\}$ \\
MeHg concentration $(\mathrm{ng} / \mathrm{g})$ & $90(4)\{65-122\}$ & $100(8)\{40-150\}$ \\
Proportion of Hg represented by MeHg & $0.972(0.014)\{0.893-1.058\}$ & $0.981(0.010)\{0.924-1.052\}$
\end{tabular}

Note: The mean values of the first six attributes were based on 25 females and 26 males; The mean values of the $\mathrm{MeHg}$ attributes were based on 13 females and 17 males.

At the grand mean for age (mean = 13.1 years), ANCOVA estimates of the Hg concentrations for males and females were $106 \mathrm{ng} / \mathrm{g}$ and $99 \mathrm{ng} / \mathrm{g}$, respectively (Figure 1). Thus, males were 7\% higher in $\mathrm{Hg}$ concentration than females. This sex difference in the $\mathrm{Hg}$ concentrations was not significant (ANCOVA: $F=1.46 ; d f=1,48 ; p=0.2331$ ). The ANCOVA model explained $38 \%$ of the variation in the $\mathrm{Hg}$ concentrations. The covariate, age, had a significant effect on the Hg concentration (ANCOVA: $F=28.94 ; d f=1,48 ; p<0.0001)$. The equality of slopes assumption for the ANCOVA was met $(F=1.87$; $d f=1,47 ; p=0.1777)$. 


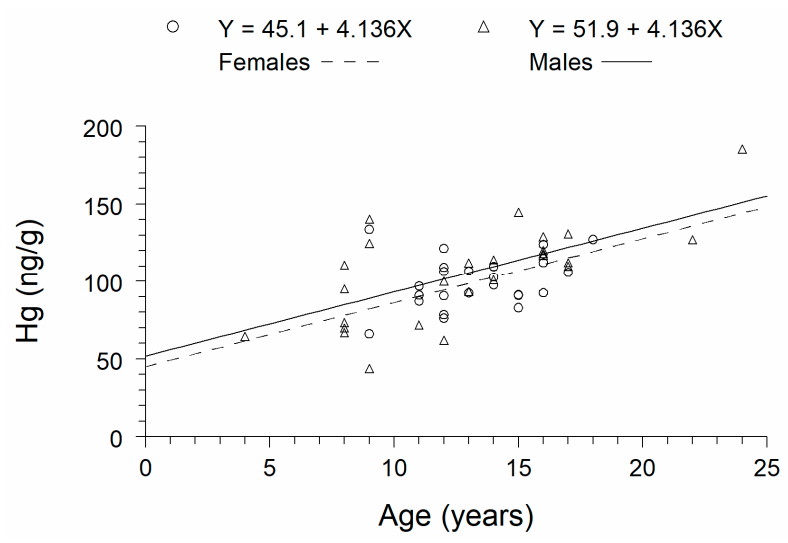

Figure 1. Whole-fish $\mathrm{Hg}$ concentration as a function of white sucker age, by sex. The fitted lines were from the application of analysis of covariance (ANCOVA), with the whole-fish $\mathrm{Hg}$ concentration as the dependent variable, age as the covariate, and sex as the main effect. The sex effect in the ANCOVA was not significant (ANCOVA: $F=1.46 ; d f=1,48 ; p=0.2331$ ). The equality of slopes assumption for the ANCOVA was met $(F=1.87 ; d f=1,47 ; p=0.1777)$. The white suckers were caught in April 2016 in the Kewaunee River (Wisconsin, USA), a tributary to Lake Michigan.

On average, $\mathrm{MeHg}$ represented $98 \%$ of the $\mathrm{Hg}$ found in the white suckers. The contribution of $\mathrm{MeHg}$ to $\mathrm{Hg}$ did not appreciably vary between the sexes. On average, $\mathrm{MeHg}$ represented $97.2 \%$ and $98.1 \%$ of the $\mathrm{Hg}$ found in the females and the males, respectively (Table 1).

At the grand mean for condition (mean $=1.04$ ), ANCOVA estimates for the ratio of the $\mathrm{Hg}$ concentration to the PCB concentration for the females and the males were 0.61 and 0.47 , respectively (Figure 2). Thus, for a given PCB concentration, the females were $29 \%$ higher in $\mathrm{Hg}$ concentration than the males. This sex difference in the ratio of the $\mathrm{Hg}$ concentration to the $\mathrm{PCB}$ concentration was significant (ANCOVA: $F=5.14 ; d f=1,48 ; p=0.0280$ ). The ANCOVA model explained $10 \%$ of the variation in the ratios of the $\mathrm{Hg}$ concentration to the $\mathrm{PCB}$ concentration. A significant effect of the covariate, $K$, on the ratio of the $\mathrm{Hg}$ concentration to the $\mathrm{PCB}$ concentration was not detected (ANCOVA: $F=3.14 ; d f=1,48 ; p=0.0829)$. The equality of slopes assumption for the ANCOVA was met $(F=1.80$; $d f=1,47 ; p=0.1866)$.

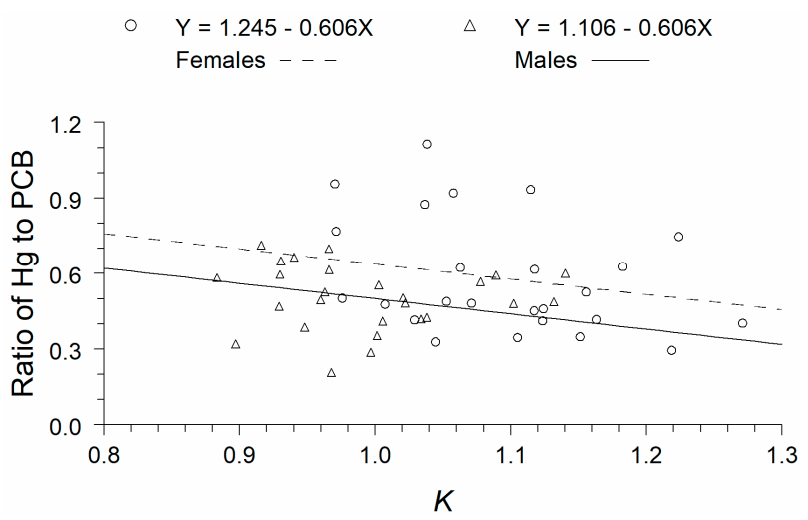

Figure 2. Ratio of whole-fish Hg concentration to whole-fish PCB concentration as a function of Fulton's condition $K$ of white sucker, by sex. The fitted lines were from the application of analysis of covariance (ANCOVA), with the ratio of the whole-fish $\mathrm{Hg}$ concentration to the whole-fish PCB concentration as the dependent variable, $K$ as the covariate, and sex as the main effect. The sex effect in the ANCOVA was significant (ANCOVA: $F=5.14 ; d f=1,48 ; p=0.0280$ ). The equality of slopes assumption for the ANCOVA was met $(F=1.80 ; d f=1,47 ; p=0.1866)$. The white suckers were caught in April 2016 in the Kewaunee River (Wisconsin, USA), a tributary to Lake Michigan. 


\section{Discussion}

We concluded that sex significantly interacted with the contaminant type (Hg or PCBs) in regulating contaminant concentrations in mature white suckers from the Kewaunee River population in Lake Michigan. We found that males were 7\% higher in $\mathrm{Hg}$ concentration than females. In contrast, males were $18 \%$ higher in PCB concentration than females [33]. Thus, the effect of sex on the $\mathrm{Hg}$ concentration was significantly different from the effect of sex on the PCB concentration. This interaction effect has now been documented in six different fish populations: lake trout from Lake Ontario, burbot from Lake Erie and Great Slave Lake, lake whitefish from Lake Huron, summer flounder from the New Jersey coast, and white sucker from Lake Michigan. In all six cases, the ratio of the PCB concentration in males to the PCB concentration in females exceeded the ratio of the $\mathrm{Hg}$ concentration in males to the $\mathrm{Hg}$ concentration in females. The most likely cause for the discrepancy in the two ratios for a given fish population is that males excrete $\mathrm{Hg}$ from their bodies at a substantially faster rate than females, whereas long-term elimination of PCBs by fish has been characterized as negligible for both sexes [24]. Of the six fish populations, the least discrepancy between the two ratios was found in the Lake Michigan white sucker population, implying that the white sucker population showed the smallest relative difference in $\mathrm{Hg}$-elimination rates between the sexes of all six fish populations. The greatest discrepancy between the two ratios was found in the burbot populations, indicating that the relative difference in $\mathrm{Hg}$-elimination rates between the sexes was greatest for burbot [24]. As previously mentioned, androgens like testosterone and 11-ketotestosterone are believed to boost the $\mathrm{Hg}$-elimination rate in male fish. Coincidentally, the relative testes size of male burbot (average gonadosomatic index $(\mathrm{GSI})=11 \%$ ) is among the largest of all fishes [24]. The GSI of male white suckers from three Ontario (Canada) lakes averaged about 6\% [41], which is considered a relatively high GSI for male fish. As postulated by Madenjian et al. [24,42], factors other than the GSI of males, along with the GSI of males, contribute to the relative difference in Hg-elimination rates between the sexes. Endocrine disruptors have been linked to reduced concentrations of androgens in male fish [43], and endocrine disruptors have also been linked to testicular tumors in mammals [44]. Hence, in theory, endocrine disruption could have contributed to the relatively modest difference in the two ratios for the Kewaunee River white suckers. However, although testicular tumors have been observed in male white suckers from the Milwaukee River and Sheboygan River populations of Lake Michigan, testicular tumors have not been found in the male white suckers from the Kewaunee River population [45]. Thus, the endocrine disruption hypothesis was not supported by the available data.

The whole-fish $\mathrm{Hg}$ concentration in the males exceeding that of the females in the Kewaunee River white sucker population was most likely attributable to males expending energy at a higher rate than females. The whole-fish PCB concentration in males exceeding that of females has now been shown in nine species of fish [24,33], and Madenjian et al. [24] concluded that the relative difference in PCB concentrations between the sexes is primarily driven by an energy expenditure rate difference between the sexes. In some cases, the sex difference in the PCB concentrations is also mediated by the growth dilution effect. The higher rate of energy expenditure by males derives from greater swimming activity by males and a higher resting metabolic rate (or standard metabolic rate (SMR)) in males. A higher rate of energy expenditure results in a greater rate of food consumption, which, in turn, results in a higher rate of PCB accumulation [24]. Because males presumably eliminate $\mathrm{Hg}$ at a faster rate than females, the ratio of the $\mathrm{Hg}$ concentration in males to the $\mathrm{Hg}$ concentration in females is less than the ratio of the PCB concentration in males to the PCB concentration in females. Thus, in teleost fishes, males are not only ingesting $\mathrm{Hg}$ at a higher rate than females, but males are also discharging $\mathrm{Hg}$ from their bodies at a higher rate than females [24]. Males also ingest PCBs at a higher rate than females. However, long-term elimination of PCBs is negligible for both sexes. Correspondingly, the whole-fish PCB concentration of males has exceeded the whole-fish PCB concentration of females in all fish populations that have been investigated [24,33]. If the difference in Hg-elimination rates between the sexes is sufficiently large, the $\mathrm{Hg}$ concentration in females will exceed the $\mathrm{Hg}$ concentration in males; this appears to be the case for burbot from Lake Erie and Great Slave Lake and lake whitefish from 
Lake Huron [24]. For Kewaunee River white suckers, the sex difference in the Hg-elimination rates was apparently relatively modest, and accordingly, the $\mathrm{Hg}$ concentration of the males was greater than the $\mathrm{Hg}$ concentration of the females.

An alternative explanation for the observed higher $\mathrm{Hg}$ concentration in the white sucker males compared with the white sucker females is that habitat use or diet composition differed between the sexes, but this hypothesis was not supported by the available data. A difference in carbon and nitrogen stable isotope ratios between the sexes may reflect a difference in habitat utilization and/or a difference in food habits between the sexes [24,46,47]. However, carbon and nitrogen stable isotope ratios did not significantly vary between the sexes of white suckers from the Kewaunee River population based on the results from an earlier study [48], indicating that this explanation was unlikely. Moreover, the PCB congener and homolog distributions did not significantly differ between the sexes of white suckers from the Kewaunee River population [49], corroborating the contention that habitat use and food habits did not vary between the sexes. Because the females grew faster than the males, the growth dilution effect could have also contributed to the males having a greater $\mathrm{Hg}$ concentration than the females. Nevertheless, the predominant factor for the observed sex difference in the $\mathrm{Hg}$ concentrations was likely a sex difference in energy expenditure rates, as generally concluded by Madenjian et al. [24].

Our estimate of $98 \%$ of the $\mathrm{Hg}$ found in the white suckers from the Kewaunee River population of Lake Michigan being MeHg was in accord with most of the other such estimates over a wide variety of fish populations. For example, $92 \%$ of the $\mathrm{Hg}$ in summer flounder from the New Jersey coast was $\mathrm{MeHg}$ [42], 91\% of the $\mathrm{Hg}$ in burbot from Great Slave Lake was $\mathrm{MeHg}$ [50], and 91\% of the $\mathrm{Hg}$ in lake whitefish from Lake Huron was MeHg [51]. Further, all (100\%) of the Hg in Lake Erie burbot and Lake Michigan lake trout was estimated to be $\mathrm{MeHg}$ [18,50]. Similarly, between 94 and 100\% of the $\mathrm{Hg}$ found in muscle tissue of 11 of 12 species of fish was $\mathrm{MeHg}$, while $86 \%$ of the $\mathrm{Hg}$ found in its muscle tissue was $\mathrm{MeHg}$ in one of the 12 species of fish [52]. The percentage of $\mathrm{Hg}$ represented by $\mathrm{MeHg}$ was somewhat less in Lake Michigan alewife (Alosa pseudoharengus), with the mean value between 60 and $70 \%$ [18]. In contrast, only $16 \%$ of the $\mathrm{Hg}$ in fillets of white perch (Morone americana) from the Hackensack River (New Jersey, USA), an area where mercury was directly discharged via industrial activity, was $\mathrm{MeHg}$, and the remaining $84 \%$ was inorganic mercury [19].

The magnitude of the $\mathrm{Hg}$ contamination in the white suckers from the Kewaunee River population of Lake Michigan was much lower than that in the white sucker populations from aquatic ecosystems heavily contaminated with mercury and was comparable with that in white suckers from aquatic ecosystems lacking any anthropogenic point source inputs of mercury. We estimated that the whole-fish $\mathrm{Hg}$ concentrations of adult white suckers from the Kewaunee River population averaged $103 \mathrm{ng} / \mathrm{g}$. In stark contrast, the average whole-fish $\mathrm{Hg}$ concentration of white suckers from Clay Lake (Ontario, Canada) was estimated to be about $2000 \mathrm{ng} / \mathrm{g}$ [53], based on the Becker and Bigham [54] conversion factor specifying that fillet $\mathrm{Hg}$ concentration is greater than whole-fish $\mathrm{Hg}$ concentration by a factor of 1.1. Clay Lake has been heavily contaminated with mercury from the operation of a chlor-alkali facility within its watershed. The Hg concentrations in the white suckers from the Kewaunee River population of Lake Michigan were similar to the $\mathrm{Hg}$ concentrations determined in the white suckers from three pristine lakes from northern Québec (Canada). No mercury has been directly discharged into these three lakes, and no logging activities or other industrial activities have occurred near any of these three lakes [55]. The mean fillet $\mathrm{Hg}$ concentration of 400-mm white suckers from these three lakes was estimated to be $98 \mathrm{ng} / \mathrm{g}$. An application of the abovementioned conversion factor yielded an estimate of the whole-fish $\mathrm{Hg}$ concentration of $88 \mathrm{ng} / \mathrm{g}$. The mean TL of the 51 white suckers sampled in our study was $465 \mathrm{~mm}$. Using a fitted regression line, we estimated that a 400-mm white sucker from the Kewaunee River population would have a whole-fish $\mathrm{Hg}$ concentration of $84 \mathrm{ng} / \mathrm{g}$. Thus, the $\mathrm{Hg}$ concentration in the Kewaunee River white suckers was similar to the $\mathrm{Hg}$ concentration in the white suckers from the three northern Québec lakes. In addition, the $\mathrm{Hg}$ concentration in the white suckers from the Kewaunee River population was lower than the $\mathrm{Hg}$ concentration in the white suckers from Lake Diefenbaker, a reservoir in Saskatchewan (Canada) with no known upstream anthropogenic point 
sources of mercury. The muscle tissue Hg concentrations of Lake Diefenbaker white suckers averaged $161 \mathrm{ng} / \mathrm{g}$ [56]. Applying the abovementioned conversion factor yielded an estimate of the whole-fish $\mathrm{Hg}$ concentration of $145 \mathrm{ng} / \mathrm{g}$. The mean weight of the white suckers sampled from Lake Diefenbaker (932 g) was slightly lower than mean weight of the white suckers sampled from the Kewaunee River spawning run $(1079 \mathrm{~g})$. Of course, factors other than the presence or absence of anthropogenic point sources of mercury also affect the $\mathrm{Hg}$ accumulation in fish. For example, the enlargement of lakes to form reservoirs, via flooding of neighboring forest-covered and muskeg-covered land, has been to shown to enhance the $\mathrm{Hg}$ accumulation in fish $[57,58]$. Apparently, the growth and activity of methylating microorganisms is stimulated by terrestrial organic matter (remains of dead plants) added to the reservoir ecosystem by the flooding used to create the reservoir. In turn, this increased methylation of mercury leads to the increased availability of methylmercury in the reservoir ecosystem, which results in increased $\mathrm{Hg}$ accumulation in reservoir fish. This reservoir effect would explain the higher Hg concentrations observed in the white suckers from Lake Diefenbaker, a reservoir, compared with the white suckers from the Kewaunee River population of Lake Michigan and the white suckers from the three abovementioned northern Québec lakes.

Our white sucker $\mathrm{Hg}$ data could be used to inform the decision-making process for formulating fish consumption advisories on white suckers from Lake Michigan. The mean and maximum whole-fish $\mathrm{Hg}$ concentrations of the white suckers from our study were 103 and $185 \mathrm{ng} / \mathrm{g}$, respectively. The application of the Becker and Bigham [54] correction factor showed that all of the fillet $\mathrm{Hg}$ concentrations of the white suckers from our study were estimated to be less than $204 \mathrm{ng} / \mathrm{g}$. The U.S. Food and Drug Administration (FDA) threshold for $\mathrm{Hg}$ concentration in fish consumed by people is $1000 \mathrm{ng} / \mathrm{g}$ [17]. Thus, all of the Kewaunee River white sucker fillet Hg concentration estimates were well below the FDA guideline. For protection of human health, the USEPA has set a water quality criterion of $\mathrm{Hg}$ concentration in fish fillets of lower than $300 \mathrm{ng} / \mathrm{g}$ [59]. All of the estimates of Kewaunee River white sucker fillet $\mathrm{Hg}$ concentration were below the USEPA criterion as well. However, even more stringent guidelines have been issued by Great Lakes state agencies for the sensitive population, which includes pregnant women, women of childbearing age, and children under the age of 15 [60,61]. According to these more stringent guidelines, fillets containing Hg concentrations between 50 and $220 \mathrm{ng} / \mathrm{g}$ should be consumed no more than once a week by the sensitive population. All but one of the estimates of Kewaunee River white sucker fillet $\mathrm{Hg}$ concentration were within this range, and therefore, limited consumption of these fillets by the sensitive population would be advised by the Great Lakes state agencies.

\section{Conclusions}

The whole-fish $\mathrm{Hg}$ concentration of mature white suckers caught during the spring spawning run in the Kewaunee River, a tributary to Lake Michigan, was 7\% higher in males than in females. In an earlier study, the whole-fish PCB concentration of these same white suckers was estimated to be $18 \%$ higher in males than in females [33]. The contaminant type (Hg or PCBs)—sex interaction was found to be significant. That is, the effect of sex on the $\mathrm{Hg}$ concentration was significantly different from the effect of sex on the PCB concentration in the Kewaunee River population of white suckers from Lake Michigan. The difference between the ratio of the $\mathrm{Hg}$ concentration in the males to the $\mathrm{Hg}$ concentration in the females and the ratio of the PCB concentration in the males to the PCB concentration in the females was most likely attributable to males excreting mercury from their bodies at a substantially faster rate than females. This type of interaction between $\mathrm{Hg}, \mathrm{PCBs}$, and sex has now been documented in five species of teleost fishes: lake trout, burbot, lake whitefish, summer flounder, and white sucker. Given these findings, this characteristic of the ratio of the PCB concentration in males to the PCB concentration in females exceeding the ratio of the $\mathrm{Hg}$ concentration in males to the $\mathrm{Hg}$ concentration in females, presumably due to a higher Hg-elimination rate for males, appears to be widespread among fish populations around the world. $\mathrm{Hg}$ concentrations in these Lake Michigan white suckers were comparable to $\mathrm{Hg}$ concentrations of white suckers from 
lakes without any anthropogenic point sources of mercury. Further, $\mathrm{Hg}$ concentrations in these Lake Michigan white suckers were relatively low, well below the FDA and USEPA guidelines, and our results will be useful to fishery managers developing fish consumption advisories for Lake Michigan white suckers. About $98 \%$ of the mercury found in these Lake Michigan white suckers was in the form of methylmercury. Males exceeding females in PCB concentration was most likely primarily driven by males expending energy at a faster rate than females, deriving from greater activity and a higher SMR. A higher energy expenditure rate resulted in a higher food consumption rate, which resulted in a higher PCB accumulation rate. We also point out that using determinations of contaminant concentrations in muscle tissue (or liver tissue), rather than whole-fish determinations, to infer the relative difference in contaminant concentrations between the sexes on a whole-fish basis could potentially mask the significance of the abovementioned contaminant type-sex interaction [24]. In some cases, the relative difference in PCB or Hg concentrations between the sexes, on a whole-fish basis, is accurately captured by using $\mathrm{PCB}$ or $\mathrm{Hg}$ determinations in muscle tissue rather than whole-fish determinations. In other cases, the relative difference in PCB or $\mathrm{Hg}$ concentrations between the sexes based on muscle tissue determinations does not accurately reflect the relative difference in $\mathrm{PCB}$ or $\mathrm{Hg}$ concentrations between the sexes on a whole-fish basis.

Author Contributions: The idea for this research was conceived by C.P.M. The field work was guided and carried out by A.L.S. and P.B.M., L.M.O., M.A.S., and C.P.M. homogenized the white suckers, while W.H.E. determined the ages of the white suckers. D.P.K., J.F.D., and J.M.O. were responsible for determining the $\mathrm{Hg}$ and $\mathrm{MeHg}$ concentrations. The statistical analyses were conducted by C.P.M., C.P.M., A.L.S., M.A.S., D.P.K., J.F.D., J.M.O., W.H.E., L.M.O., and P.B.M. contributed to the writing of the manuscript.

Funding: This research received no external funding.

Acknowledgments: Tim Desorcie assisted with the homogenization of the fish. The authors also thank Steve Lengnick for photographing the homogenization procedure and Martin Perales for his assistance with the field work. Scott Hansen reviewed the manuscript and made helpful suggestions for its improvement. The use of trade, product, or firm names does not imply endorsement by the U.S. Government.

Conflicts of Interest: The authors declare no conflict of interest.

\section{References}

1. Boening, D.W. Ecological effects, transport, and fate of mercury: A general review. Chemosphere 2000, 40, 1335-1351. [CrossRef]

2. Driscoll, C.T.; Mason, R.P.; Chan, H.M.; Jacob, D.J.; Pirrone, N. Mercury as a global pollutant: Sources, pathways, and effects. Environ. Sci. Technol. 2013, 47, 4967-4983. [CrossRef] [PubMed]

3. Wiener, J.G.; Krabbenhoft, D.P.; Heinz, G.H.; Scheuhammer, A.M. Ecotoxicology of Mercury. In Handbook of Ecotoxicology, 2nd ed.; Hoffman, D.J., Rattner, B.A., Burton, G.A., Jr., Cairns, J., Jr., Eds.; CRC Press: Boca Raton, FL, USA, 2003; pp. 407-461.

4. Storelli, M.M. Potential human health risks from metals $(\mathrm{Hg}, \mathrm{Cd}$, and $\mathrm{Pb})$ and polychlorinated biphenyls (PCBs) via seafood consumption: Estimation of target hazard quotients (THQs) and toxic equivalents (TEQs). Food Chem. Toxicol. 2008, 46, 2782-2788. [CrossRef] [PubMed]

5. Clarkson, T.W.; Magos, L.; Myers, G.J. The toxicology of mercury-Current exposures and clinical manifestations. N. Engl. J. Med. 2003, 349, 1731-1737. [CrossRef] [PubMed]

6. Zahir, F.; Rizwi, S.J.; Haq, S.K.; Khan, R.H. Low dose mercury toxicity and human health. Environ. Toxicol. Pharmacol. 2005, 20, 351-360. [CrossRef] [PubMed]

7. Scheuhammer, A.M.; Meyer, M.W.; Sandheinrich, M.B.; Murray, M.W. Effects of environmental methylmercury on the health of wild birds, mammals, and fish. Ambio 2007, 36, 12-18. [CrossRef]

8. Sandheinrich, M.B.; Bhavsar, S.P.; Bodaly, R.A.; Drevnick, P.E.; Paul, E.A. Ecological risk of methylmercury to piscivorous fish of the Great Lakes region. Ecotoxicology 2011, 20, 1577-1587. [CrossRef] [PubMed]

9. Azevedo, B.F.; Furieri, L.B.; Peçanha, F.M.; Wiggers, G.A.; Vassallo, P.F.; Simões, M.R.; Fiorim, J.; Rossi de Batista, P.; Fioresi, M.; Rossoni, L.; et al. Toxic effects of mercury on the cardiovascular and central nervous systems. J. Biomed. Biotechnol. 2012, 2012, 949048. [CrossRef] 
10. Wiener, J.G.; Evers, D.C.; Gay, D.A.; Morrison, H.A.; Williams, K.A. Mercury contamination in the Laurentian Great Lakes region: Introduction and overview. Environ. Pollut. 2012, 161, 243-251. [CrossRef] [PubMed]

11. Rice, K.M.; Walker, E.M., Jr.; Wu, M.; Gillette, C.; Blough, E.R. Environmental mercury and its toxic effects. J. Prev. Med. Public Health 2014, 47, 74-83. [CrossRef] [PubMed]

12. Somers, E.C.; Ganser, M.A.; Warren, J.S.; Basu, N.; Wang, L.; Zick, S.M.; Park, S.K. Mercury exposure and antinuclear antibodies among females of reproductive age in the United States: NHANES. Environ. Health Perspect. 2015, 123, 792-798. [CrossRef] [PubMed]

13. Ginsberg, G.L.; Toal, B.E. Development of a single-meal fish consumption advisory for methyl mercury. Risk Anal. 2000, 20, 41-47. [CrossRef] [PubMed]

14. Burger, J.; Gochfeld, M.; Powers, C.W.; Waishwell, L.; Warren, C.; Goldstein, B.D. Science, policy, stakeholders, and fish consumption advisories: Developing a fish fact sheet for the Savannah River. Environ. Manag. 2001, 27, 501-514. [CrossRef]

15. Pastorok, R.A.; Bartell, S.M.; Ferson, S.; Ginzburg, L.R. Ecological Modeling in Risk Assessment: Chemical Effects on Populations, Ecosystems, and Landscapes; Lewis: Boca Raton, FL, USA, 2002.

16. McClain, W.C.; Chumchal, M.M.; Drenner, R.W.; Newland, L.W. Mercury concentrations in fish from Lake Meredith, Texas: Implications for the issuance of fish consumption advisories. Environ. Monit. Assess. 2006, 123, 249-258. [CrossRef] [PubMed]

17. Cai, Y.; Rooker, J.R.; Gill, G.A.; Turner, J.P. Bioaccumulation of mercury in pelagic fishes from the Northern Gulf of Mexico. Can. J. Fish. Aquat. Sci. 2007, 64, 458-469. [CrossRef]

18. Raymond, B.; Rossmann, R. Total and methyl mercury accumulation in 1994-1995 Lake Michigan lake trout and forage fish. J. Great Lakes Res. 2009, 35, 438-446. [CrossRef]

19. Weis, P.; Ashley, J.T.F. Contaminants in fish of the Hackensack Meadowlands, New Jersey: Size, sex, and seasonal relationships as related to health risks. Arch. Environ. Contam. Toxicol. 2007, 52, 80-89. [CrossRef] [PubMed]

20. Mason, R.P.; Sullivan, K.A. Mercury in Lake Michigan. Environ. Sci. Technol. 1997, 31, 942-947. [CrossRef]

21. Marvin, C.; Painter, S.; Rossmann, R. Spatial and temporal patterns in mercury contamination in sediments of the Laurentian Great Lakes. Environ. Res. 2004, 95, 351-362. [CrossRef] [PubMed]

22. Jeremiason, J.D.; Kanne, L.A.; Lacoe, T.A.; Hulting, M.; Simcik, M.F. A comparison of mercury cycling in Lakes Michigan and Superior. J. Great Lakes Res. 2009, 35, 329-336. [CrossRef]

23. Lepak, R.F.; Krabbenhoft, D.P.; Ogorek, J.M.; Tate, M.T.; Bootsma, H.A.; Hurley, J.P. Influence of Cladophora-quagga mussel assemblages on nearshore methylmercury production in Lake Michigan. Environ. Sci. Technol. 2015, 49, 7606-7613. [CrossRef] [PubMed]

24. Madenjian, C.P.; Rediske, R.R.; Krabbenhoft, D.P.; Stapanian, M.A.; Chernyak, S.M.; O'Keefe, J.P. Sex differences in contaminant concentrations of fish: A synthesis. Biol. Sex Differ. 2016, 7, 42. [CrossRef] [PubMed]

25. Madenjian, C.P.; Blanchfield, P.J.; Hrenchuk, L.E.; Van Walleghem, J.L.A. Mercury elimination rates for adult northern pike Esox lucius: Evidence for a sex effect. Bull. Environ. Contam. Toxicol. 2014, 93, 144-148. [CrossRef] [PubMed]

26. Cooke, S.J.; Bunt, C.M.; Hamilton, S.J.; Jennings, C.A.; Pearson, M.P.; Cooperman, M.S.; Markle, D.F. Threats, conservation strategies, and prognosis for suckers (Catostomidae) in North America: Insights from regional case studies of diverse family of non-game fishes. Biol. Conserv. 2005, 121, 317-331. [CrossRef]

27. Doosey, M.H.; Bart, H.L., Jr. Morphological variation of the palatal organ and chewing pad of Catostomidae (Teleostei: Cypriniformes). J. Morphol. 2011, 272, 1092-1108. [CrossRef] [PubMed]

28. Childress, E.S.; Allan, J.D.; McIntyre, P.B. Nutrient subsidies from iteroparous fish migrations can enhance stream productivity. Ecosystems 2014, 17, 522-534. [CrossRef]

29. Scott, W.B.; Crossman, E.J. Freshwater Fishes of Canada; Fisheries Research Board of Canada Bulletin 184: Ottawa, ON, Canada, 1973.

30. Michigan Department of Natural Resources. Michigan Suckers Are Popular with Spring Anglers. 2012. Available online: http:/ / www.michigan.gov/dnr/0,4570,7-153-275299-RSS,00.html (accessed on 1 August 2018).

31. Munkittrick, K.R.; Dixon, D.G. Use of white sucker (Catostomus commersoni) populations to assess the health of aquatic ecosystems exposed to low-level contaminant stress. Can. J. Fish. Aquat. Sci. 1989, 46, 1455-1462. [CrossRef] 
32. Blazer, V.S.; Hoffman, J.; Walsh, H.L.; Braham, R.P.; Hahn, C.; Collins, P.; Jorgenson, Z.; Ledder, T. Health of white sucker within the St. Louis River area of concern associated with habitat usage as assessed using stable isotopes. Ecotoxicology 2014, 23, 236-251. [CrossRef] [PubMed]

33. Madenjian, C.P.; Stevens, A.L.; Stapanian, M.A.; Batterman, S.A.; Chernyak, S.M.; Menczer, J.E.; McIntyre, P.B. Sex difference in PCB concentrations of a catostomid fish. J. Environ. Anal. Toxicol. 2017, 7, 515. [CrossRef]

34. American Fisheries Society. Guidelines for the Use of Fishes in Research. 2004. Available online: https: / / fisheries.org/docs/policy_useoffishes.pdf (accessed on 1 August 2018).

35. USGS Mercury Research Laboratory. Methods Used for Common Analysis Types: Plant and Animal Tissue. Available online: http:/ / wi.water.usgs.gov/mercury-lab/research/analysis-methods.html (accessed on 1 August 2018).

36. United States Environmental Protection Agency. Method 7473: Mercury in Solids and Solutions by Thermal Decomposition, Amalgamation, and Atomic Absorption Spectrophotometry; USEPA, Office of Water: Washington, DC, USA, 2007.

37. United States Environmental Protection Agency. Guidelines Establishing Test Procedures for the Analysis of Pollutants (Appendix B, Part 136, Definition of Procedures for the Determination of Method Detection Limit-Revision 1.11, Revised July 1, 1999); USEPA, Office of Water: Washington, DC, USA, 1990.

38. Hammerschmidt, C.R.; Fitzgerald, W.F. Bioaccumulation and trophic transfer of methylmercury in Long Island Sound. Arch. Environ. Contam. Toxicol. 2006, 51, 416-424. [CrossRef] [PubMed]

39. Sylvester, R.M.; Berry, C.R., Jr. Comparison of white sucker age estimates from scales, pectoral fin rays, and otoliths. N. Am. J. Fish. Manag. 2006, 26, 24-31. [CrossRef]

40. Edwards, W.H.; Stapanian, M.A.; Stoneman, A.T. An evaluation of precision in age estimation of two treatments of otoliths from an aging burbot population. J. Appl. Ichthyol. 2011, 27 (Suppl. S1), 43-48. [CrossRef]

41. Trippel, E.A.; Harvey, H.H. Reproductive responses of five white sucker (Catostomus commersoni) populations in relation to lake acidity. Can. J. Fish. Aquat. Sci. 1987, 44, 1018-1023. [CrossRef]

42. Madenjian, C.P.; Jensen, O.P.; Krabbenhoft, D.P.; DeWild, J.F.; Ogorek, J.M.; Vastano, A.R. Mercury accumulation and the mercury-PCB-sex interaction in summer flounder. J. Mar. Sci. Res. Dev. 2016, 6, 188. [CrossRef]

43. Pollock, M.S.; Dubé, M.G.; Schryer, R. Investigating the link between pulp mill effluent and endocrine disruption: Attempts to explain the presence of intersex fish in the Wabigoon River, Ontario, Canada. Environ. Toxicol. Chem. 2010, 29, 952-965. [CrossRef] [PubMed]

44. Bay, K.; Asklund, C.; Skakkebaek, N.E.; Andersson, A.-M. Testicular dysgenesis syndrome: Possible role of endocrine disrupters. Best Pract. Res. Clin. Endocrinol. Metabol. 2006, 20, 77-90. [CrossRef] [PubMed]

45. Blazer, V.S.; Walsh, H.L.; Braham, R.P.; Hahn, C.M.; Mazik, P.; McIntyre, P.B. Tumours in white suckers from Lake Michigan tributaries: Ppathology and prevalence. J. Fish Dis. 2017, 40, 377-393. [CrossRef] [PubMed]

46. Madenjian, C.P.; Yule, D.L.; Chernyak, S.M.; Begnoche, L.J.; Berglund, E.K.; Isaac, E.J. Males exceed females in PCB concentrations of cisco (Coregonus artedi) from Lake Superior. Sci. Total Environ. 2014, 493, 377-383. [CrossRef] [PubMed]

47. Madenjian, C.P.; Jensen, O.P.; Rediske, R.R.; O'Keefe, J.P.; Vastano, A.R.; Pothoven, S.A. Differences in energy expenditures and growth dilution explain higher PCB concentrations in male summer flounder. PLoS ONE 2016, 11, e0147223. [CrossRef] [PubMed]

48. Stevens, A.L. Mercury in Wisconsin Fishes: Pathological and Consumption Implications. Master's Thesis, University of Wisconsin, Madison, WI, USA, 2016.

49. Stapanian, M.A.; Madenjian, C.P.; Batterman, S.A.; Chernyak, S.M.; Edwards, W.H.; McIntyre, P.B. Distributions of PCB congeners and homologues in white sucker and coho salmon from Lake Michigan. Environ. Sci. Technol. 2018, 52, 4393-4401. [CrossRef] [PubMed]

50. Madenjian, C.P.; Stapanian, M.A.; Cott, P.A.; Krabbenhoft, D.P.; Edwards, W.H.; Ogilvie, L.M.; Mychek-Londer, J.G.; DeWild, J.F. Females exceed males in mercury concentrations of burbot Lota lota. Arch. Environ. Contam. Toxicol. 2015, 68, 678-688. [CrossRef] [PubMed]

51. Madenjian, C.P.; Ebener, M.P.; Krabbenhoft, D.P. Mercury accumulation, and the mercury-PCB-sex interaction, in lake whitefish (Coregonus clupeaformis). Environments 2016, 3, 7. [CrossRef]

52. Bloom, N.S. On the chemical form of mercury in edible fish and marine invertebrate tissue. Can. J. Fish. Aquat. Sci. 1992, 49, 1010-1017. [CrossRef]

53. Scott, D.P. Mercury concentration of white muscle in relation to age, growth, and condition in four species of fishes from Clay Lake, Ontario. J. Fish. Res. Board Can. 1974, 31, 1723-1729. [CrossRef] 
54. Becker, D.S.; Bigham, G.N. Distribution of mercury in the aquatic food web of Onondaga Lake, New York. Water Air Soil Pollut. 1995, 80, 563-571. [CrossRef]

55. Surette, C.; Lucotte, M.; Tremblay, A. Influence of intensive fishing on the partitioning of mercury and methylmercury in three lakes of Northern Québec. Sci. Total Environ. 2006, 368, 248-261. [CrossRef] [PubMed]

56. Donald, D.B.; Wissel, B.; Anas, M.U.M. Species-specific mercury bioaccumulation in a diverse fish community. Environ. Toxicol. Chem. 2015, 34, 2846-2855. [CrossRef] [PubMed]

57. Jackson, T.A. Biological and environmental control of mercury accumulation by fish in lakes and reservoirs of Northern Manitoba, Canada. Can. J. Fish. Aquat. Sci. 1991, 48, 2449-2470. [CrossRef]

58. Bodaly, R.A.; Fudge, R.J.P. Uptake of mercury by fish in an experimental boreal reservoir. Arch. Environ. Contam. Toxicol. 1999, 37, 103-109. [CrossRef] [PubMed]

59. United States Environmental Protection Agency. Water Quality Criterion for the Protection of Human Health: Methylmercury; EPA-823-R-01-001; USEPA, Office of Water: Washington, DC, USA, 2001.

60. Stevens, A.L.; Baird, I.G.; McIntyre, P.B. Differences in mercury exposure among Wisconsin anglers arising from fish consumption preferences and advisory awareness. Fisheries 2018, 43, 31-41. [CrossRef]

61. A Protocol for Mercury-Based Fish Consumption Advice: An Addendum to the 1993 Protocol for a Uniform Great Lakes Sport Fish Consumption Advisory. 2007. Available online: https:/ /www.in.gov/isdh/files/ Mercury_Protocol.pdf (accessed on 1 August 2018).

(C) 2018 by the authors. Licensee MDPI, Basel, Switzerland. This article is an open access article distributed under the terms and conditions of the Creative Commons Attribution (CC BY) license (http:/ / creativecommons.org/licenses/by/4.0/). 